\title{
List of species in the genus Lutzomyia, França, 1924 (Psychodidae, Phlebotominae) from the State of Mato Grosso
}

\author{
Lista das espécies do gênero Lutzomyia, França, 1924 (Psychodidae, \\ Phlebotominae) do Estado de Mato Grosso
}

\author{
Nanci Akemi Missawa ${ }^{1}$ and Giovana Belem Moreira Lima Maciel ${ }^{1}$
}

\begin{abstract}
This work had the objective of listing the sand fy species that occur in the State of Mato Grosso, Brazil. Data relating to entomological surveys conducted between 1996 and 2004 were obtained from the National Health Foundation and the State Health Department, and this was supplemented with information from research carried out in the state and from the specialized literature. There were records of 106 sand fy species belonging to the genus Lutzomyia. This is a rich and diversified fauna, with some species restricted to forested areas and others recorded throughout the state, independent of the vegetation type, and in areas modified by buman action, with predominance of Lutzomyia whitmani.
\end{abstract}

Key-words: Lutzomyia. Sand fy fauna. Mato Grosso.

\section{RESUMO}

o presente trabalho teve como objetivo listar as espécies de flebotomíneos que ocorrem no Estado de Mato Grosso, Brasil. Os dados foram obtidos junto à Fundação Nacional de Saúde e à Secretaria Estadual de Saúde, referente às pesquisas entomológicas desenvolvidas entre 1996 e 2004, complementadas com informações de pesquisas desenvolvidas no Estado e bibliografia especializada. Foram registradas 106 espécies de flebotomineos pertencentes ao gênero Lutzomyia. Esta é uma rica e diversificada fauna, com algumas espécies restritas a áreas florestais e outras registradas em todo o Estado, independente da formação vegetal e em áreas modificadas pela ação antrópica, com predominância de Lutzomyia whitmani.

Palavras-chaves: Lutzomyia. Fauna de flebotomíneos. Mato Grosso.

Among the entomological research carried out in the State of Mato Grosso, Aguiar and Medeiros ${ }^{1}$ presented a list of sand flies; De Luca et $\mathrm{al}^{5}$ studied the distribution of sand flies in Alta Floresta, in the northern region of the state; Costa et $\mathrm{al}^{4}$ and Rodrigues et $\mathrm{al}^{13}$ developed entomological domestication studies in the mid-northern and mid-southern regions; Ribeiro and Missawa ${ }^{12}$ described the spatial distribution of sand flies in the state, with emphasis on the species related to leishmaniasis transmission; Azevedo et $\mathrm{al}^{2}$ identified 26 sand fly species in Peixoto de Azevedo, in the northern region of the state; Moura ${ }^{9}$ developed an epidemiological survey on canine leishmaniasis in Cuiabá; Ribeiro et al ${ }^{11}$ carried out a study on leishmaniasis vectors in the area influenced by the Manso power station; Ribeiro and Missawa ${ }^{112}$ investigated the occurrence of Lutzomyia longipalpis in the city of Várzea Grande; and $\mathrm{Cipa}^{3}$ dealt with the state as a whole.
Studies on the geographic regions where sand flies occur contribute towards better comprehension of the epidemiological aspects of leishmaniasis. The present study had the objective of listing the sand flies species that occur in the State of Mato Grosso.

\section{MATERIAL AND METHODS}

The State of Mato Grosso is situated in the central-western region of Brazil, with an area of 903,358 square kilometers, and it has 2,803,274 inhabitants . Mato Grosso forms the watershed between the Plate and Amazon Basins, the two biggest hydrographic basins on the continent and it contains three of the most important Brazilian vegetation zones: the Amazon forest, the savanna and the Pantanal marshland. The annual rainfall distribution shows the tropical character of the area, with two well-defined seasons: one dry and the other wet?

\footnotetext{
1. Laboratório de Entomologia/Gerência de Vigilância de Vetores e Antropozoonoses/Coordenadoria de Vigilância em Saúde Ambiental/Superintendência de Vigilância em Saúde/Secretaria Estadual de Saúde de Mato Grosso. Cuiabá, MT.

Address to: Dra. Nanci Akemi Missawa. Rua Tailândia 888, Bairro Shangri-lá. 78070-195 Cuiabá, MT, Brasil.

Telefone: 65 3661-2934. Fax: 65 3661-2494

e-mail:_nanci@cpqrr.fiocruz.br

Recebido para publicação em 8/5/2006

Aceito em 2/1/2007
} 
Mato Grosso is considered to be the biggest agricultural expansion frontier in Brazil. Over the last few years it has defined the process of internal development in Brazil. The occupation of economic space, in terms of both the migrants becoming established as smallholders in settlement projects and the big agricultural and pastoral companies, has consolidated the position of Mato Grosso as the Agricultural State .

The present study consists of a report on species of the genus Lutzomyia that occur in the State of Mato Grosso. The data were mainly obtained from the National Health Foundation's Regional Coordination Office for Mato Grosso (FUNASA/CORE/ MT) and from the Entomology Laboratory of the Vector and Anthropozoonosis Surveillance Directorate, Environmental Health Surveillance Coordination Office, Health Surveillance Superintendency, State Health Department (SES/MT). These data related to an entomological survey that was developed between 1996 and 2004, as identified by Young and Duncan ${ }^{15}$, and were supplemented with information from studies carried out in the state and from the specialized literature.

\section{RESULTS}

The research that was carried out recorded 106 sand fly species belonging to the genus Lutzomyia. These were distributed in the following subgenera: Evandromyia (5), Lutzomyia (12), Micropygomyia (2), Nyssomyia (11), Pintomyia (3), Pressatia (3), Psathyromyia (8), Psychodopygus (15), Sciopemyia (3), Trichophoromyia (6), Trichopygomyia (3) and Viannamyia (2); and in the groups: Aragaoi (6), Baityi (1), Dreisbachi (2), Migonei (12), Oswaldoi (6), Saulensis (2) and Verrucarum (2); plus two species without a defined group, as shown in Table 1.

The entomological survey carried out by FUNASA and SES/MT listed, among other species: L. amazonensis, L. andersoni, L. auraensis, L. brisolai, L. chagasi, L. choti, L. christenseni, L. clitella, L. corumbaensis, L. cruciata, L. dasymera, L. dreisbachi, L. dubitans, L. dysponeta, L. fischeri, L. goiana, L. hirsuta nicaraguensis, L. howardi, L. inflata, L. intermedia, L. longispina, L. microps, L. olmeca bicolor, L. ruii, L. servulolimai and L. termitophila.

Aguiar and Medeiros ${ }^{1}$ published a list of sand flies from the central-western region consisting of 98 species, among which: L. baityi, L. bispinosa, L. coutinhoi, L. damascenoi, L. evangelistai, L. falcata, L. flabellata, L. geniculata, L. gomezi, L. guyanensis, L. lichyi, L. marinkellei, L. oliveirai, L. pusilla, L. richardwardi and L. sherlocki.

Azevedo $e t a l^{2}$ identified L. spathotrichia and others in the state, and Moura ${ }^{9}$ observed L. olmeca nociva in Cuiabá.

In the present study, all the species listed in Table 1 were observed in the Amazon forest area, except for L. brisolai, L. corumbaensis, L. dasymera and L. dysponeta.

The species that occurred in the forest area were: L. baityi, L. bispinosa, L. campbelli, L. coutinhoi, L. damascenoi, L. evangelistai, L. falcata, L. flabellata, L. geniculata, L. gomezi, L. guyanensis, L. hirsuta hirsuta, L. hirsuta nicaraguensis,
L. lichyi, L. marinkellei, L. monstruosa, L. octavioi, L. oliveirai, L. pusilla, L. richardwardi, L. sherlocki and L. spathotrichia.

The species that were observed in the Amazon forest, transition area, savanna and Pantanal were: L. acanthopharynx, L. amazonensis, L. andersoni, L. antunesi, L. aragaoi, L. auraensis, L. carmelinoi, L. christenseni, L. cruzi, L. davisi, L. dendrophyla, L. dubitans, L. evandroi, L. flaviscutellata, L. goiana, L. bermanlenti, L. lenti, L. longipalpis, L. longipennis, L. longispina, L. lutziana, L. migonei, L. nevesi, L. punctigeniculata, L. quinquefer, L. runoides, L. sallesi, L. saulensis, L. scaffi, L. shannoni, L. sordellii, L. teratodes, L. termitophila, L. walkeri and L. whitmani.

\section{DISCUSSION}

The great diversity of sand fly fauna observed in Mato Grosso must be due to the presence of different types of vegetation, with areas of Amazon forest in the northern region of the state, savanna in the central and mid-southern regions, and vast transition areas between forest, savanna and marshland in the southern extremity of the state.

Aguiar and Medeiros ${ }^{1}$ argued that although species like L. cortelezzii, L. missionensis, L. monticola and L. pessoai occurred in the central-western region of Brazil, they were not found in Mato Grosso. They also highlighted the absence of $L$. microps from the region. Lutzomyia ubiquitalis was demonstrated in the state, in forest, transition and savanna area. This species was described as having a regional distribution in the Brazilian Amazon region according to these authors. Lutzomyia runoides was captured in different types of vegetation in the state, thus decreasing the discontinuity between the State of Rondônia and the southeastern region of the country, where it was recorded and classified as having discontinuous distribution.

Among the endemic species in the northern region ${ }^{1}$, the following have been captured in Mato Grosso: L. auraensis, L. begonae, L. chagasi, L. dasymera, L. dreisbachi, L. dubitans, L. inflata, L. llanosmartinsi, L. olmeca bicolor, L. paraensis, L. ruii, L. servulolimai, L. shawi, L. spathotrichia and L. wilsoni.

The species listed in Mato Grosso that have been implicated as or suspected of being capable of transmitting Leishmania to humans and animals in Brazil are: L. ayrozai, L. flaviscutellata, L. longipalpis, L. paraensis, L. ubiquitalis, L. whitmani ${ }^{18}{ }^{15}$, L. anduzei, L. antunesi, L. umbratilis ${ }^{15}$, L. cruzi, L. intermedia ${ }^{18}$, L. carrerai carrerai, L complexa, L. yuilli yuilli ${ }^{8}$, L. gomezi, L. migonei, L. olmeca bicolor, L. olmeca nociva and L. tuberculata ${ }^{1}$.

The local fauna was partially described by Ribeiro and Missawa $^{12}$, who observed 88 sand fly species. The diversity is characterized by an overlapping of vector fauna and probably of the etiological agents for leishmaniasis, with the respective reservoirs in neighboring states, since Mato Grosso is situated in the central-western region of Brazil. Thus, connections with the northern, northeastern, southeastern and southern regions of the country are established, and these connections have great epidemiological importance. 
Table 1 - Species in the Genus Lutzomyia from the State of Mato Grosso, Brazil.

\begin{tabular}{|c|c|c|c|}
\hline Genus & Subgenus & Groups & Species \\
\hline \multirow[t]{20}{*}{$\begin{array}{l}\text { Lutzomyia } \\
\text { França, } 1924\end{array}$} & $\begin{array}{c}\text { Evandromyia } \\
\text { Mangabeira, } 1941\end{array}$ & & $\begin{array}{l}\text { L. begonae (Ortiz \& Torres, 1975), L. bourrouli (Barretto \& Coutinho, 1941), } \\
\text { L. infraspinosa (Mangabeira, 1941), L. monstruosa (Floch \& Abonnenc, 1944), } \\
\text { L. teratodes Martins, Falcão \& Silva, } 1964\end{array}$ \\
\hline & $\begin{array}{l}\text { Lutzomyia } \\
\text { França, } 1924\end{array}$ & & $\begin{array}{l}\text { L. cruciata (Coquillett, 1907), L. cruzi (Mangabeira, 1938), L. dispar Martins \& Silva, } \\
\text { 1963, L. evangelistai Martins \& Fraiha, 1971, L. falcata Young, Morales \& Ferro, 1994, } \\
\text { L. flabellata Martins \& Silva, 1964, L. gomezi (Nitzulescu, 1931), L. lichyi (Floch \& } \\
\text { Abonnenc, 1950), L. longipalpis (Lutz \& Neiva, 1912), L. marinkellei Young, 1979, L. } \\
\text { sherlocki Martins, Silva \& Falcão, 1971, L. spathotrichia Martins, Falcão \& Silva, 1963 }\end{array}$ \\
\hline & $\begin{array}{l}\text { Micropygomyia } \\
\text { Barretto, } 1462\end{array}$ & & L. micropyga (Mangabeira, 1942), L. oliveirai Martins, Silva \& Falcão, 1970 \\
\hline & $\begin{array}{l}\text { Nyssomyia } \\
\text { Barretto, } 1462\end{array}$ & & $\begin{array}{l}\text { L. anduzei (Rozeboom, 1942), L. antunesi (Coutinho, 1939), L. flaviscutellata } \\
\text { (Mangabeira, 1942), L. intermedia (Lutz \& Neiva, 1912), L. olmeca bicolor Fairchild } \\
\text { \& Theodor, 1971, L. olmeca nociva Young \& Arias, 1982, L. richardwardi Ready \& } \\
\text { Fraiha, 1981, L. shawi Fraiha, Ward \& Ready, 1981, L. umbratilis Ward \& Fraiha, } 1977 \text {, } \\
\text { L. whitmani (Antunes \& Coutinho, 1939), L. yuilli yuilli Young \& Porter, } 1972\end{array}$ \\
\hline & $\begin{array}{c}\text { Pintomyia } \\
\text { Costa Lima, } 1932\end{array}$ & & $\begin{array}{l}\text { L. christenseni Young \& Duncan, 1994, L. damascenoi (Mangabeira, 1941), } \\
\text { L. fischeri (Pinto, 1926) }\end{array}$ \\
\hline & $\begin{array}{c}\text { Pressatia } \\
\text { Mangabeira, } 1942\end{array}$ & & $\begin{array}{l}\text { L. choti (Floch \& Abonnenc, 1941), L. dysponeta (Fairchild \& Hertig, 1952), } \\
\text { L. triancantha (Mangabeira, 1942) }\end{array}$ \\
\hline & $\begin{array}{l}\text { Psathyromyia } \\
\text { Barretto, } 1962\end{array}$ & & $\begin{array}{l}\text { L. abonnenci (Floch \& Chassignet, 1947), L. campbelli (Damasceno, Causey \& Arouck, } \\
\text { 1945), L. dendrophyla (Mangabeira, 1942), L. dasymera (Fairchild \& Hertig, 1961), } \\
\text { L. lutziana (Costa Lima, 1932), L. punctigeniculata (Floch \& Abonnenc, 1944), } \\
\text { L. scaffi (Damasceno \& Arouck, 1956), L. shannoni (Dyar, 1929) }\end{array}$ \\
\hline & $\begin{array}{l}\text { Psychodopygus } \\
\text { Mangabeira, } 1941\end{array}$ & & $\begin{array}{l}\text { L. amazonensis (Root, 1934), L. ayrozai (Barretto \& Coutinho, 1940), L. bispinosa } \\
\text { (Fairchild \& Hertig, 1951), L. carrerai carrerai (Barretto, 1946), L. chagasi (Costa } \\
\text { Lima, 1941), L. claustrei Abonnenc, Léger \& Fauran, 1979, L. complexa (Mangabeira, } \\
\text { 1941), L. davisi (Root, 1934), L. geniculata (Mangabeira, 1941), L. guyanensis } \\
\text { (Floch \& Abonnenc, 1941), L. birsuta hirsuta (Mangabeira, 1942), L. birsuta } \\
\text { nicaraguensis (Fairchild \& Hertig, 1961), L. lainsoni (Fraiha \& Ward, 1974), } \\
\text { L. llanosmartinsi (Fraiha \& Ward, 1980), L. paraensis (Costa Lima, 1941) }\end{array}$ \\
\hline & $\begin{array}{l}\text { Sciopemyia } \\
\text { Barretto, } 1962\end{array}$ & & $\begin{array}{l}\text { L. microps (Mangabeira, 1942), L. servulolimai (Damasceno \& Causey, 1945), } \\
\text { L. sordellii (Shannon \& Del Ponte, 1927) }\end{array}$ \\
\hline & $\begin{array}{l}\text { Trichophoromyia } \\
\text { Barretto, } 1962\end{array}$ & & $\begin{array}{l}\text { L. auraensis (Mangabeira, 1942), L. clitella Young \& Pérez, 1994, L. howardi } \\
\text { Young, 1979, L. octavioi (Vargas, 1949), L. ruii Arias \& Young, 1982, L. ubiquitalis } \\
\text { (Mangabeira, 1942) }\end{array}$ \\
\hline & $\begin{array}{l}\text { Trichopygomyia } \\
\text { Barreto, } 1962\end{array}$ & & $\begin{array}{l}\text { L. dasypodogeton (Castro, 1939), L. longispina (Mangabeira, 1942), L. rondonensis } \\
\text { Martins, Falcão \& Silva, } 1965\end{array}$ \\
\hline & $\begin{array}{c}\text { Viannamyia } \\
\text { Mangabeira, } 1941\end{array}$ & & L. furcata (Mangabeira, 1941), L. tuberculata (Mangabeira, 1941) \\
\hline & & $\begin{array}{c}\text { Aragaoi } \\
\text { (Theodor, 1965) }\end{array}$ & $\begin{array}{l}\text { L. aragaoi (Costa Lima, 1932), L. barrettoi barrettoi (Mangabeira, 1942), } \\
\text { L. brasiliensis (Costa Lima, 1932), L. coutinhoi (Mangabeira, 1942), L. inflata } \\
\text { (Floch \& Abonnenc, 1944), L. runoides (Fairchild \& Hertig, 1953) }\end{array}$ \\
\hline & & $\begin{array}{c}\text { Baityi } \\
\text { Theodor, } 1965\end{array}$ & L. baityi (Damasceno, Causey \& Arouck, 1945) \\
\hline & & $\begin{array}{c}\text { Dreisbachi } \\
\text { (Lewis et al, 1977) }\end{array}$ & $\begin{array}{l}\text { L. dreisbachi (Causey \& Damasceno, 1945), L. hermanlenti Martins, Silva \& Falcão, } \\
1970\end{array}$ \\
\hline & & $\begin{array}{l}\text { Migonei } \\
\text { Theodor, } 1965\end{array}$ & $\begin{array}{l}\text { L. andersoni Le Pont \& Desjeux, 1988, L. baculus Martins, Falcão \& Silva, } \\
\text { L. carmelinoi Ryan, Fraiha, Lainson \& Shaw, 1986, L. corumbaensis Galati, Nunes, } \\
\text { Oshiro \& Rego, 1989, L. dubitans (Sherlock, 1962), L. evandroi (Costa Lima \& } \\
\text { Antunes, 1936), L. lenti (Mangabeira, 1938), L. migonei (França, 1920), L. sallesi } \\
\text { (Galvão \& Coutinho, 1939), L. sericea (Floch \& Abonnenc, 1944), L. termitophila } \\
\text { Martins, Falcão \& Silva, 1964, L. walkeri (Newstead, 1914) }\end{array}$ \\
\hline & & $\begin{array}{c}\text { Oswaldoi } \\
\text { (Theodor, 1965) }\end{array}$ & $\begin{array}{l}\text { L. goiana Martins, Falcão \& Silva, 1962, L. longipennis (Barretto, 1946), L. peresi } \\
\text { (Mangabeira, 1942), L. pusilla Dias, Martins, Falcão \& Silva, 1986, L. quinquefer } \\
\text { (Dyar, 1929), L. trinidadensis (Newstead, 1922) }\end{array}$ \\
\hline & & $\begin{array}{l}\text { Saulensis } \\
\text { (Lewis et al, 1977) }\end{array}$ & L. saulensis (Floch \& Abonnenc, 1944), L. wilsoni (Damasceno \& Causey, 1945) \\
\hline & & $\begin{array}{l}\text { Verrucarum } \\
\text { Theodor, } 1965\end{array}$ & L. nevesi (Damasceno \& Arouck, 1956), L. serrana (Damasceno \& Arouck, 1949) \\
\hline & & * & $\begin{array}{l}\text { L. acanthopharynx Martins, Falcão \& Silva, 1962, L. brisolai Le Pont \& Desjeux, } \\
1987\end{array}$ \\
\hline
\end{tabular}

\footnotetext{
* species without a defined group
} 
This is a rich and diversified fauna, with some species restricted to the forested areas, while others are recorded all over the state, independent of the vegetation zone, and in areas modified by human action.

The visceral leishmaniasis vector, L. longipalpis, is a very eclectic species in relation to its dietary habits, with high ecological valence. It can therefore adapt to environments with diverse characteristics and inhabit ecosystems going from hostile dry regions to areas modified by human action ${ }^{6}$, and from coastal regions to exposed locations ${ }^{10} . L$. cruzi, which has been implicated as vector for Leishmania chagasi in Mato Grosso do Sul ${ }^{814}$, with widespread distribution across the state.

The species L. whitmani, which presents widespread uniform distribution in the state and has been recorded both within and around homes, is probably the best-adapted species ${ }^{12}{ }^{13}$. L. antunes $i$ is prevalent in the forest canopy ${ }^{2}$. L. migone $i$ is found in wetter $\operatorname{areas}^{6}$ and is a species found in all five regions of Brazil ${ }^{1}$. It has been observed in Mato Grosso, in areas with all types of vegetation. $L$. flaviscutellata has been recorded in these same areas and, although it is considered extremely wild, it has moved into areas around and inside homes, thus indicating differentiated behavior, as observed by Rebêlo et a $\mathrm{l}^{10}$.

Lutzomyia intermedia is considered to be the most important vector for cutaneous leishmaniasis in southeastern Brazil and it occurs in the states neighboring Mato Grosso, such as Tocantins, Goiás, Federal District and Mato Grosso do Sul ${ }^{1}$. L. ayrozai is predominantly found in areas around homes and in areas adjacent to forests ${ }^{6}$. It occurs in all of the vegetation types in Mato Grosso, excepted in the marshland.

According to Aguiar and Medeiros ${ }^{1}$, L. carrerai carrerai and L. yuilli yuilli occurs in all of the Brazilian regions, except for the southern region, while $L$. anduze $i$ is found in the northern, northeastern and central-western regions. These species present distribution in all the vegetation types, with exception of marshland. L. gomez $i$ has the same occurrence as $L$. anduze $i$ and has been observed exclusively in forest areas, while $L$. tuberculata is in forest and savanna.

The species L. complexa, L. olmeca bicolor, L. olmeca nociva, L. ubiquitalis and $L$. umbratilis are important vectors in the Amazon region, occurring in forest, transition and savanna areas, except for L. olmeca nociva, which has only been observed in the savanna.

We can communicate that this is the first record of L. clitella in Brazil, and the specimen is stored at the International Phlebotomine Reference Center at the René Rachou Research Center, Fundação Oswaldo Cruz, in Belo Horizonte City, Brazil.

\section{ACKNOWLEDGMENTS}

We are grateful to the technicians at the Entomology Laboratory (FUNASA and SES/MT) for the information and good working relationships while preparing the present work.

\section{REFERENCES}

1. Aguiar GM, Medeiros WM. Distribuição e Habitats. In: Rangel EF, Lainson R (cols) Flebotomíneos do Brasil. Editora da Fundação Oswaldo Cruz. Rio de Janeiro p. 207-255, 2003.

2. Azevedo ACR, Souza NA, Meneses CRV, Costa WA, Lima JB, Rangel EF. Ecology of sand flies (Diptera: Psychodidae: Phlebotominae) in the north of State of Mato Grosso, Brazil. Memórias do Instituto Oswaldo Cruz 97: 459-464, 2002.

3. Computer-aided Identification of Phlebotominae Sandflies of America (CIPA). Phlebotominae Species of Mato Grosso, Brazil. CIPA, 1999. http://www.cipa.snv. jussieu.fr. accessed on Feb 1, 2005.

4. Costa LB, Bertúlio MA, Rodrigues H, Lima GBM, Ramos SR, Moraes Filho VC, Ribeiro ALM, Souza CO, Silva AM, Barros IM. Ocorrência de Flebotomíneos Vetores da Leishmaniose Visceral nos Municípios do Estado de Mato Grosso. Revista da Abrasco 8: 639, 2003.

5. De Luca AS, Vasconcelos HL, Barrett TV. Distribution of sandflies (Diptera: Phlebotominae) in forest remnants and adjacent matrix habitats in Brazilian Amazonian. Jornal Brasileiro de Biologia 63:401-410, 2003.

6. Dias-Lima AG, Guedes MLS, Sherlock IA. Horizontal stratification of the sand fly fauna (Diptera: Psychodidae) in a transitional vegetation between caatinga and tropical rain forest, State of Bahia, Brazil. Memórias do Instituto Oswaldo Cruz 98:733-737, 2003.

7. Ferreira JCV. Mato Grosso e seus Municípios. Editora Buriti. Cuiabá/MT, 2001.

8. Marcondes CB. Entomologia Médica e Veterinária. Editora Atheneu. São Paulo, 2001.

9. Moura ST. Inquérito Epidemiológico da Leishmaniose Canina na Área Urbana de Cuiabá, Estado de Mato Grosso, Brasil (1997-1998) e alguns comentários sobre o gênero Lutzomyia frança (1924) nesta região. Doctoral thesis. Cuiabá/MT, 2000.

10. Rebêlo JM, Araújo J, Carvalho M, Oliveira ST, Silva FS. Flebótomos (Diptera, Phlebotominae) da ilha de São Luis, zona do Golfão Maranhense, Brasil. Revista da Sociedade Brasileira de Medicina Tropical 32:247-253, 1999.

11. Ribeiro ALM, Missawa NA. Ocorrência de Flebotomíneos no Município de Várzea Grande/ Mato Grosso, no período de abril a setembro de 2001. Simpósio Amazônia e Ambiente. Cuiabá/MT, 2002a.

12. Ribeiro ALM, Missawa NA. Spatial distribution of Phlebotominae species in the State of Mato Grosso, Brazil, in the period of 1996 to 2001. Entomología y Vectors 9: 33-34, 2002b.

13. Rodrigues H, Missawa NA, Costa LB, Lima GBM, Ramos SR, Moraes Filho VC, Souza CO, Ribeiro ALM, Silva AM, Barros IM. A interferência Humana Como Fator de Agravamento Ambiental e a Domiciliação dos Vetores da Leishmaniose Tegumentar Americana no Estado de Mato Grosso, no Período de 2001 e 2002. Revista da Abrasco 8: 414, 2003.

14. Santos SO, Arias J, Ribeiro AA, Hoffmann MP, Freitas RU, Malacco MAF. Incrimination of Lutzomyia cruzi as a vector of American Visceral Leishmaniasis. Medical and Veterinary Entomology 12:315-317, 1998.

15. Young DG, Duncan MA. Guide to the identification and geographic distribution of Lutzomyia sand files in México, the West Indies, Central and South America (Diptera: Psychodidae). Associated Publishers American Entomological Institute, Florida/ USA, 1994. 